\title{
Glutathione S-Transferase Isoenzymes in Rat Brain Neurons and Glia
}

\author{
Jeffrey A. Johnson, ,a Aida El Barbary, ${ }^{2, b}$ Steven E. Kornguth,, ${ }^{3,4}$ John F. Brugge, ${ }^{2}$ and Frank L. Siegel ${ }^{1,4,5}$ \\ ${ }^{1}$ Environmental Toxicology Center, Departments of ${ }^{2}$ Neurophysiology, ${ }^{3}$ Neurology, ${ }^{4}$ Biomolecular Chemistry, and \\ ${ }^{5}$ Pediatrics, and the Waisman Center, University of Wisconsin, Madison, Wisconsin 53705
}

The glutathione S-transferases (GSTs) constitute a family of cytosolic isoenzymes and a structurally unrelated microsomal enzyme that is involved in the detoxication of electrophilic xenobiotics. These enzymes also participate in the intracellular binding and transport of a broad range of lipophilic compounds including bilirubin, and hormones such as the glucocorticoids and thyroid hormones. The present investigation demonstrates that GSTs are present in neurons of the brainstem, forebrain, and cerebellum. An isoenzymespecific distribution of GSTs was found in cytoplasm, nuclei, and nucleoli.

The regional and cellular distribution of cytosolic GSTs in the brain was studied by immunohistochemistry, spectrophotometric enzyme assay, and reverse-phase HPLC. Polyclonal antibody against microsomal GST was strongly reactive with Purkinje cells throughout the cerebellar cortex, and with neurons in the brainstem and hippocampus. Nuclei of Purkinje cells and of neurons in the brainstem, hippocampus, and cerebral cortex were immunopositive for $\alpha$-class GST 1-1 $\left(Y_{a} Y_{a}\right)$, whereas $\alpha$-class GST 2-2 $\left(Y_{c} Y_{c}\right)$ antibody was consistently immunoreactive with the nucleolus, but not with the nucleus or soma. All $\alpha$-class GST antibodies studied were reactive, to various degrees, with astrocytes and choroid plexus; however, ependymal cells of the subventricular zones were immunonegative. $\alpha$-class GST 8-8 $\left(Y_{k} Y_{k}\right)$ immunoreactivity was specifically localized to endothelial cells and/or astrocytic end feet associated with blood vessels.

Reverse-phase HPLC indicated that there were also substantial regional differences in the pattern of $\alpha-\mu$-, and $\pi$-class GST subunit expression. For example, the thalamus/ hypothalamus had the highest GST activity and greatest concentration of total GST protein and $\mu$-class GST subunit 6 $\left(Y_{b 3}\right)$, whereas the brainstem had the greatest concentration of $\pi$-class GST subunit $\left(Y_{p}\right)$. This regional variation in GST expression may be reflective of regional differences in cell populations. In cerebellar cortex, the concentration of $\mu$-class

\footnotetext{
Received Jan. 23, 1992; revised Sept. 14, 1992; accepted Nov. 17, 1992.

We thank Drs. Miles Epstein and Kenneth Mack for their helpful discussion of this work and Ms. Elaine Langer for expert assistance in histology. This research was supported by NIH Grants NS24969 and HD03352. J.A.J. was supported by National Service Award T32 ES07015 from the National Institutes of Environmental Health Sciences. This report is contribution 254 from the Environmental Toxicology Center, University of Wisconsin.

Correspondence should be addressed to Frank L. Siegel, Ph.D., University of Wisconsin, Room 655 Waisman Center, 1500 Highland Avenue, Madison, WI 53706.

a Present address: University of Washington, Department of Pharmacology SJ30, School of Medicine, Seattle, WA 98195.

b Present address: University of Michigan, Department of Otolaryngology, Kresege Hearing Institute, 1301 East Ann Street, Ann Arbor, MI 48109.

Copyright (C) 1993 Society for Neuroscience 0270-6474/93/132013-1 1\$05.00/0
}

GST subunit $4\left(Y_{b_{2}}\right)$ was greatest in the flocculus and lowest in the vermis. This is of clinical interest because the pattern of expression of $\mu$-class GST subunit $4\left(Y_{b 2}\right)$ in the cerebellum coincides with the known regional susceptibility of this structure to degeneration after exposure to toxic or metabolic insults. The vermis is most susceptible to these insults, whereas the lateral lobes and flocculus are most resistant. The nuclear localization of $\alpha$-class GSTs in neurons, the cytoplasmic localization of microsomal GST in neurons, and the association between concentration of $\mu$-class GST subunit $4\left(Y_{b_{2}}\right)$ and resistance of neurons to toxic events in the cerebellar cortex suggest that GSTs may confer protection against exogenous and/or endogenous neurotoxic metabolites.

[Key words: glutathione S-transferase, neurons, Purkinje cells, Bergmann glia, cerebellum, immunohistochemical localization, HPLC]

Glutathione $S$-transferases (GSTs; EC 2.5.1.18) constitute a family of multifunctional enzymes that are involved in metabolic detoxication of a variety of electrophilic xenobiotics (Ketterer et al., 1988; Mannervik and Danielson, 1988; Vos and Van Bladeren, 1990). Cytosolic GSTs are present in most mammalian organs and exist as dimeric proteins consisting of two identical or closely related subunits from the same class $(\alpha, \mu$, $\pi, \theta$; Mannervik and Danielson, 1988; Meyer et al., 1991). Rat tissues contain at least 20 dimers made up of 15 different subunits (Tu et al., 1983; Ketterer et al., 1988; Mannervik and Danielson, 1988; Kispert et al., 1989; Hayes et al., 1990a,b; Hiratsuka et al., 1990; Tsuchida and Sato, 1990; Harris et al., 1991; Hayes et al., 1991; Meyer et al., 1991). Microsomal GST is a homotrimer consisting of a subunit that is structurally distinct from the cytosolic enzymes (Morgenstern and DePierre, 1985; Morgenstern et al., 1985). Cytosolic GST isoenzyme profiles are altered in preneoplastic foci, tumor tissue, and multidrug-resistant cell lines (Satoh et al., 1985; Cowan et al., 1986; Moscow et al., 1989). Enzymatic activity is regulated at the transcriptional level by a variety of inducing compounds (Pickett et al., 1984; Ding et al., 1986; Lee et al., 1986; Benson et al., 1989; Di Simplicio et al., 1989; Rushmore et al., 1990). In contrast, no compounds have been shown to increase hepatic concentrations of microsomal GST (Morgenstern and DePierre, 1985; McLellan and Hayes, 1989; McLellan et al., 1991). Posttranslational regulation of GSTs is also suggested by reports that GSTs are activated by active oxygen species (Murata et al., 1990 ), that $\alpha$-class GSTs are substrates for protein kinase C (Pyerin et al., 1987; Taniguchi and Pyerin, 1989), and that $\mu$-class GSTs are methylated by specific methyltransferases (Neal et al., 1988; Johnson et al., 1990, 1992a). 
GSTs have been shown to be involved in intracellular transport mechanisms and the binding of endogenous nonsubstrate ligands (Listowsky et al., 1988). These enzymes bind thyroid hormones L-3, 3', 5-triiodothyronine $\left(\mathrm{T}_{3}\right)$ and L-3,3',5,5'-tetraiodothyronine $\left(\mathrm{T}_{4}\right)$, which have been shown to control cerebellar development (Kornguth et al., 1967; Kornguth et al., 1979; Legrand, 1979; Silva and Rudas, 1990; Legrand and Clos, 1991). GSTs also bind bilirubin, which is toxic to the cerebellum (Schutta and Johnson, 1967; Sawasaki et al., 1976; Takagishi and Yamamura, 1989), and are postulated to be involved in cellular uptake and intracellular transport of bilirubin (Listowsky et al., 1988). Li et al. (1986) demonstrated the tissue-specific expression of a unique $\mu$-class GST polyA RNA species in rat brain and the expression of $\alpha$-class $Y_{c}$, but not $Y_{a}, R N A$ in rat brain. In addition, a gene encoding the $\mu$-class GST $6\left(\mathrm{Y}_{\mathrm{b} 3}\right)$ protein was found to be selectively expressed in rat brain (Abramovitz and Listowsky, 1987). At least two isoenzymes have been localized to glial cells in human, rat, and mouse brain (Senjo and Ishibashi, 1985; Senjo et al., 1986; Abramovitz et al., 1988; Cammer et al., 1989; Carder et al., 1990; Campbell ct al., 1991; Tansey and Cammer, $1991 \mathrm{a}, \mathrm{b})$. In rats and mice, the $\mu$-class isoenzymes were immunohistochemically localized in astrocytes, subventricular zone cells, ependymal cells, and tanycytes, whereas $\pi$-class GST was found in oligodendrocytes (Abramovitz et al., 1988; Cammer et al., 1989; Tansey and Cammer, $1991 \mathrm{~b}$ ) and associated with myelin (Tansey and Cammer, 1991a). In human brains, either $\alpha$-class isoenzymes were not detectable or immunoreactivity was inconsistent (Carder et al., 1990; Campbell et al., 1991). Neurons in rat and mouse brain were not immunoreactive with either $\mu$ - or $\pi$-class GST antibodies (Abramovitz et al., 1988; Cammer et al., 1989; Tansey and Cammer, 1991a), and in humans, neurons were immunonegative for antibodies against $\alpha-, \mu$-, and $\pi$-class GSTs (Carder et al., 1990; Campbell et al., 1991). To date, the immunohistochemical distribution of cytosolic $\alpha$-class GSTs in rodent brain and microsomal GST in rodent and human brain remains unknown. The present investigation was designed to: (1) identify, by immunohistochemical methods, the cells of the rat brain that were immunopositive for cytosolic GST isoenzymes of the $\alpha$-, $\mu$-, and $\pi$-class, and for microsomal GST; and (2) determine, by reverse-phase HPLC, the concentrations of cytosolic $\alpha$-, $\mu$-, and $\pi$-class GST subunits in different brain regions.

\section{Materials and Methods}

Materials. Bovine serum albumin (BSA) was purchased from Sigma Chemical Company. Polyclonal rabbit anti-rat GST antisera against $\alpha$-class GST 1-1 ( $\left.\mathrm{Y}_{\mathrm{a}} \mathrm{Y}_{\mathrm{a}}\right)$, GSI 2-2 $\left(\mathrm{Y}_{\mathrm{c}} \mathrm{Y}_{\mathrm{c}}\right)$, GST 8-8 $\left(\mathrm{Y}_{\mathrm{k}} \mathrm{Y}_{\mathrm{k}}\right)$; $\mu$-class GST 3-3 $\left(Y_{b 1} Y_{b 1}\right)$, GST 4-4 $\left(Y_{b 2} Y_{b 2}\right)$; $\pi$-class GST 7-7 $\left(Y_{p} Y_{p}\right)$; and microsomal GST were purchased from Biotrin (Dublin, Ireland). Preimmune rabbit serum was also purchased from Biotrin, and normal rabbit sera were prepared in our laboratory. Goat anti-rabbit IgG conjugated to fluorescein isothiocyanate (FITC) and normal goat serum (NGS) were from Vector Labs (Burlington, CA). $S$-hexylglutathione, glutathione (GSH), and epoxy-activated Sepharose 6B were purchased from Sigma Chemical Company and coupled as previously described (Mannervik and Guthenberg, 1981; Simons and Vander Jagt, 1981). Acetonitrile was from Burdick and Jackson Company, and trifluoroacetic acid (TFA) was from Aldrich Chemical Company. The System Gold HPLC Systcm from Beckman Instruments was used for HPLC analysis. Male Wistar rats were purchased from Harlan Sprague-Dawley (Madison, WI). All other materials were products of Sigma Chemical Company.

Immunohistochemistry. Male rats of the Wistar strain, 2-3 months old, weighing 250-300 gm, were anesthetized with sodium pentobarbital and perfused through the left ventricle with $50-75 \mathrm{ml}$ of $3 \%$ parafor- maldehyde in $0.1 \mathrm{M}$ phosphate-buffered saline (PBS; $\mathrm{pH} 7.4$ ). The paraformaldehyde-fixed brains were placed in 0.1 м PBS ( $\mathrm{pH} 7.4$ ) for $24 \mathrm{hr}$ followed by $30 \%$ sucrose in $0.1 \mathrm{M}$ PBS (pH 7.4), mounted in a block of OCT embedding medium, and stored at $-80^{\circ} \mathrm{C}$. Cryostat sections $(10$ $\mu \mathrm{m})$ were cut in the coronal plane, collected on subbed slides, encircled with a PAP pen, dried at room temperature for $15 \mathrm{~min}$, and washed in $10 \mathrm{~mm}$ PBS (pH 7.4). After three washes (10 min each) in PBS, sections were incubated in PBS containing 2\% NGS and 5\% BSA for $2 \mathrm{hr}$ at room temperature to block nonspecific staining. The sections were then covered with a solution of rabbit anti-rat GST antiserum (1:2000) in $10 \mathrm{~mm}$ PBS (pH 7.4) and incubated overnight at $4^{\circ} \mathrm{C}$. Sections were rinsed with $10 \mathrm{~mm}$ PBS (pH 7.4) and then incubated for $2 \mathrm{hr}$ at room temperature in a solution containing goat anti-rabbit IgG conjugated to FITC $(1: 100)$. The sections were rinsed again, covered with Gel Mount, and coverslips applied. Vectastain ABC Reagent kits were also used to treat some sections following the protocol of Vector Labs.

Negative control experiments were carried out by substituting preimmune rabbit sera (PRS; 1:2000) and PBS for the solution containing the rabbit anti-rat GST. To control for the specificity of the rabbit antirat GST, the primary antibody was incubated initially with purified GST antigen and then placed on the sections. A previous study using $\mu$-class GST antiserum gave an impression of localization of $\mu$-class GST in neurons (Johnson et al., 1991, 1992b).

Antihody sperificity and cross-reactivity. The antibodiès purchased from Biotrin have been used extensively for immunohistochemistry (Cammer et al., 1989; Harrison et al., 1990a; Daly et al., 1991; Tansey and Cammer, $1991 \mathrm{a}, \mathrm{b})$. The specificity and cross-reactivity have been analyzed by Western blot and are well documented (Hayes and Mantle, 1986a; Kispert et al., 1989; McLellan and Hayes, 1989; Steinberg et al., 1989; Hayes et al., 1991; McLellan et al., 1991). The $\mu$-class antibodies raised against GST 3-3 $\left(Y_{b 1} Y_{b 1}\right)$ and GST 4-4 $\left(Y_{b 2} Y_{b 2}\right)$ show strong immunological cross-reactivity with one another and with GST $6\left(Y_{b 3}\right)$ but not with GST subunits of the $\alpha$ - or $\pi$-classes. $\mu$-Class antibody against GST 4-4 $\left(\mathrm{Y}_{\mathrm{b} 2} \mathrm{Y}_{\mathrm{b} 2}\right)$ is more reactive against $\mu$-class subunit 11 $\left(Y_{o}\right)$ than against GST 3-3 $\left(Y_{b 1} Y_{b 1}\right)$. In contrast, $\alpha$-class GST 1-1 $\left(Y_{a} Y_{a}\right)$, GST 2-2 $\left(Y_{c} Y_{c}\right)$, and GST 8-8 $\left(Y_{k} Y_{k}\right)$ antisera show weak cross-reactivity with each other. The $\pi$-class GST 7-7 $\left(Y_{p} Y_{p}\right)$ and microsomal GST antibodies show no cross-reactivity with any other GSTs.

Isolation of GSTS. Male Wistar rats were killed and brains were removed. The cerebellum was dissected into flocculi, lateral hemispheres, and vermis. Brainstem, thalamus/hypothalamus, and cortex were dissected. In each experiment, brain regions from five animals were pooled and cytosolic fractions were prepared by ultracentrifugation $(100,000$ $x g$ ) of tissues homogenized in $10 \mathrm{~mm}$ Tris- $\mathrm{HCl}, \mathrm{pH} 7.8$, containing $0.25 \mathrm{~m}$ sucrose, $10 \mathrm{~mm}$ EDTA, $2.0 \mathrm{~mm}$ EGTA, and $2.0 \mathrm{~mm}$ dithiothreitol (DTT). All purification steps were carried out at $4^{\circ} \mathrm{C}$ and cytosolic fractions were stored at $-80^{\circ} \mathrm{C}$. Protein concentrations were determined by the method of Bradford (1976), with bovine $\gamma$-globulin as standard. Cytosolic GST activity was measured by assaying the amount of 1 -chloro2,4-dinitrobenzene conjugated with GSH per minute per milligram of cytosolic protein (Habig and Jakoby, 1981). GSTs were isolated from cytosolic fractions by affinity chromatography as follows: equivalent amounts of cytosolic protein from the different brain regions were loaded on an $S$-hexylglutathione-Sepharose affinity column, and the material that did not bind was immediately loaded on a GSH-Sepharose affinity column according to the method of Hayes (1988). Both columns $(0.7$ $\mathrm{cm} \times 1.0 \mathrm{~cm}$ ) were equilibrated with $10 \mathrm{~mm}$ Tris- $\mathrm{HCl}$, $\mathrm{pH} 7.8$, containing $2.0 \mathrm{mM}$ DTT (buffer A); the columns were then washed sequentially with buffer $\mathrm{A}$, buffer A containing $0.2 \mathrm{M} \mathrm{NaCl}$ (buffer $\mathrm{B}$ ), and finally eluted with $2.0 \mathrm{ml}$ of buffer B containing $5 \mathrm{~mm} S$-hexylglutathione.

Separation of GST subunits by HPLC. The small mass of tissue from the various brain regions and the low levels of GST with respect to total cytosolic protein $(0.2-0.4 \%)$ made it necessary to increase the sensitivity of our previously published HPLC technique (Johnson et al., 1992a). This was accomplished by utilizing a narrow-bore Vydac $C_{18}(2.1 \mathrm{~mm}$ $\times 25 \mathrm{~cm}) 300 \AA$ reverse-phase column, which increased the sensitivity of analysis five- to seven-fold and allowed us to determine the concentration of GST subunits in a minimum tissue mass of $20-25 \mathrm{mg}$ wet weight, with a limit of detection of any individual GST subunit of 2.0 pmol, or approximately $50 \mathrm{ng}$ of subunit protein. Solvent A was $0.1 \%$ trifluoroacetic acid in deionized water and solvent B was $70 \%$ acetonitrile and $0.1 \%$ trifluoroacetic acid in deionized water. GST subunits were resolved using a linear gradient from $36.4 \%$ to $51.8 \%$ acetonitrile over $70 \mathrm{~min}$. The flow rate was $0.25 \mathrm{ml} / \mathrm{min}$ and $\mathrm{UV}$ absorbance at 
214 and $280 \mathrm{~nm}$ was monitored. There was no evidence of memory between samples; recovery of GSTs ranged from $90 \%$ to $100 \%$. GST subunits were identified by SDS-PAGE and by comparison with previously published HPLC profiles (Hayes and Mantle 1986b; Ostlund Farrants et al., 1987; Ketterer et al., 1988; Kispert et al., 1989; Meyer et al., 1989; Hayes et al., 1990a; Hiratsuka et al., 1990; Johnson et al., $1990,1992 a)$. The amount of each GST subunit was determined from the peak height at $214 \mathrm{~nm}$, by using the molar absorptivity $\left(\epsilon_{214}\right)$ for the individual subunits (Johnson et al., 1992a). The concentrations of individual subunits were expressed as picomoles of subunit protein per milligram of cytosolic protein. These values were summed to determine the concentration of total GST subunit protein or total $\mu$-class GST subunit protein.

Statistical analysis. All groups of data were evaluated by analysis of variance and the individual means compared by the Fisher protected least significant difference test $(p<0.05)$.

\section{Results}

\section{Nonspecific binding of preimmune and normal rabbit sera}

Nonspecific binding of preimmune serum, especially to neuronal cell bodies (cytoplasmic and perinuclear), was noted at dilutions of preimmune rabbit serum of less than or equal to 1:1000, when Vectastain ABC Reagent kits were used to treat the sections. Similarly, the use of a secondary biotinylated goat anti-rabbit IgG followed by avidin conjugated to FITC resulted in a high degree of nonspecific neuronal staining. Analysis of five different normal rabbit sera (Vector Labs, and four individual rabbit sera prepared in our laboratory) showed the same type of nonspecific neuronal immunohistochemical staining. Purkinje cells of the cerebellar cortex were the most reactive with normal rabbit sera. In contrast, sections treated with goat anti-rabbit IgG (secondary antibody) conjugated to FITC markedly reduced nonspecific neuronal staining and overall background. Nonspecific staining was also reduced by further dilution of the antisera $(1: 2000)$ without loss of specific immunoreactivity. Based on these preliminary data, use of secondary biotinylated antibodies was abandoned and all subsequent investigations were performed using secondary antibody directly conjugated with FITC, and preimmune and primary rabbit antisera dilutions of 1:2000. Examples of preimmune sections are presented below (see Figs. $1 A, 2 A, 3 C, 5 A$ ). These experimental conditions allowed us to determine unequivocally the immunohistochemical identification of GST-positive neurons and glia.

\section{Immunohistochemical identification of GST-positive neurons}

Throughout the brain, neurons and glial cells were identified as immunopositive to GST antibodies. Figures 1 and 2 illustrate examples of GST-positive neurons from sections through the brainstem and cerebellar cortex, respectively. Lipofuscin is present in most neurons and, under fluorescent microscopy, appears as orange-colored grains in the neuronal cytoplasm (Figs. 1-5). Polyclonal antibody against microsomal GST was strongly reactive with the cytoplasm of neurons of the brainstem (Fig. 1 B) and Purkinje cells of the cerebellar cortex (Fig. 2B). Microsomal GST immunoreactivity was strongest in the cytosol, and in most cells both the perikaryon and the proximal segment of the main dendritic trunk were intensely labeled. This was particularly evident in Purkinje cells (Fig. $2 B$ ) and in neurons of the brainstem nuclear groups associated with the auditory, vestibular, facial, and trigeminal systems (Fig. $1 B$ ). Fine dendritic processes of Purkinje cells were also immunopositive for microsomal GST, and these fine processes permeated the molecular layer of the cerebellar cortex (Fig. 2B). Neurons of the hippocampus and proximal dendritic trunks of the hippocampal pyramidal cells were also immunopositive for microsomal GST (data not shown). Nuclei of Purkinje cells (Fig. $2 C$ ) and neurons in the brainstem (Fig. 1C) and hippocampus (data not shown) were immunopositive for $\alpha$-class GST 1-1 ( $\left.Y_{\mathrm{a}} Y_{\mathrm{a}}\right)$. A related $\alpha$-class GST 2-2 $\left(Y_{c} Y_{c}\right)$ antibody was consistently immunoreactive with the nucleolus, but with neither the nucleus nor soma of brainstem neurons and Purkinje cells (Figs. 1D, 2D).

\section{Immunohistochemical localization of GST-positive non-neuronal cells}

In contrast to the other $\alpha$-class antibodies against GST $1-1\left(Y_{\mathrm{a}} Y_{\mathrm{a}}\right)$ and GST 2-2 $\left(Y_{c} Y_{c}\right), \alpha$-class GST 8-8 $\left(Y_{k} Y_{k}\right)$ antibody showed no reactivity with either the nucleus or nucleolus of neurons, but was strongly immunoreactive with endothelial cells and/or astrocyte end-foot processes on blood vessels throughout the brain (Fig. 3A,B). All antibodies against $\alpha$-class GSTs were reactive with astrocytes (Fig. $3 A, B$ ) and choroid plexus (Fig. $3 D$ ) to varying degrees; however, cells of the ependyma and the subventricular zones were immunonegative (Fig. 3D). The choroid plexus was most intensely reactive with GST 8-8 $\left(Y_{k} Y_{k}\right)$ antibody (Fig. $3 D$ ). In addition, the choroid plexus, cells of the ependyma and subventricular zones, and pia mater were im-

Figure 1. Neuronal localization of GSTs in the brainstem. Cryosections $(10 \mu \mathrm{m})$ were incubated with A) preimmune rabbit serum $(A)$, rabbit antirat microsomal GST antiserum $(B)$, rabbit anti-rat $\alpha$-class GST 1-1 $\left(Y_{\mathrm{a}} \mathrm{Y}_{\mathrm{a}}\right)$ antiserum $(C)$, and rabbit anti-rat $\alpha$-class GST 2-2 $\left(\mathrm{Y}_{\mathrm{c}} \mathrm{Y}_{\mathrm{c}}\right)$ antiserum (D) (1:2000) overnight at $4^{\circ} \mathrm{C}$. This was followed by incubation with goat anti-rabbit IgG conjugated to FITC (1:100) for $2 \mathrm{hr}$ at room temperature. Arrows indicate immunopositive brainstem neurons. Scale bar, $20 \mu \mathrm{m}$.

Figure 2. Neuronal localization of GSTs in the cerebellar cortex. Cryosections $(10 \mu \mathrm{m})$ were incubated with pre-immune rabbit serum $(A)$, rabbit anti-rat microsomal GST antiserum $(B)$, rabbit anti-rat $\alpha$-class GST 1-1 $\left(\mathrm{Y}_{\mathrm{a}} \mathrm{Y}_{\mathrm{a}}\right)$ antiserum $(C)$, and rabbit anti-rat $\alpha$-class GST 2-2 (Y $\left.\mathrm{Y}_{\mathrm{c}} \mathrm{Y}_{\mathrm{c}}\right)$ antiserum $(D)$ as described in Figure 1. Arrows indicate immunopositive Purkinje cells that separate the molecular $(m)$ and granular $(g)$ layers. Scale bar, $20 \mu \mathrm{m}$.

Figure 3. Immunohistochemical localization of $\alpha$-class GST $8-8\left(\mathrm{Y}_{\mathrm{k}} \mathrm{Y}_{\mathrm{k}}\right)$ in the cerebellar cortex and choroid plexus. Cryosections (10 $\left.\mu \mathrm{m}\right)$ through the cerebellar cortex $(A, B)$ and the fourth ventricle $(C, D)$ were incubated with rabbit anti-rat $\alpha$-class GST 8-8 $\left(\mathrm{Y}_{\mathrm{k}} \mathrm{Y}_{\mathrm{k}}\right)$ antiserum $(A, B, D)$ and preimmune rabbit serum $(C)$ as described in Figure 1. Long arrows $(A, B)$ indicate immunopositive endothelial cells and/or astrocyte end-foot processes associated with blood vessels; short arrows $(A, B)$ indicate immunopositive astrocytes in the granular layer $(g)$ and cerebellar fiber tract (f). $m$, molecular layer. Scale bar, $20 \mu \mathrm{m}$.

Figure 4. Immunohistochemical localization of $\mu$-class GSTs in the cerebellar cortex, brainstem, ependymal cells, and choroid plexus. Cryosections $(10 \mu \mathrm{m})$ through the cerebellar cortex $(A)$, brainstem $(B)$, and the fourth ventricle $(C, D)$ were incubated with rabbit anti-rat $\mu$-class GST 4-4 (Y $\left.\mathrm{Y}_{\mathrm{b} 2} \mathrm{Y}_{\mathrm{b} 2}\right)$ antiserum $(A, B D)$ and rabbit anti-rat $\mu$-class GST 3-3 $\left(\mathrm{Y}_{\mathrm{b} 1} \mathrm{Y}_{\mathrm{b} 1}\right)$ antiserum $(C)$ as described in Figure 1. Short arrows indicate immunopositive Bergmann radial glial cells $(A)$, astrocytes $(B)$, and ependymal cells $(C, D)$. Long arrow indicates immunopositive choroid plexus $(D)$. $m$, molecular layer; $g$, granule layer. Scale bar, $20 \mu \mathrm{m}$. 

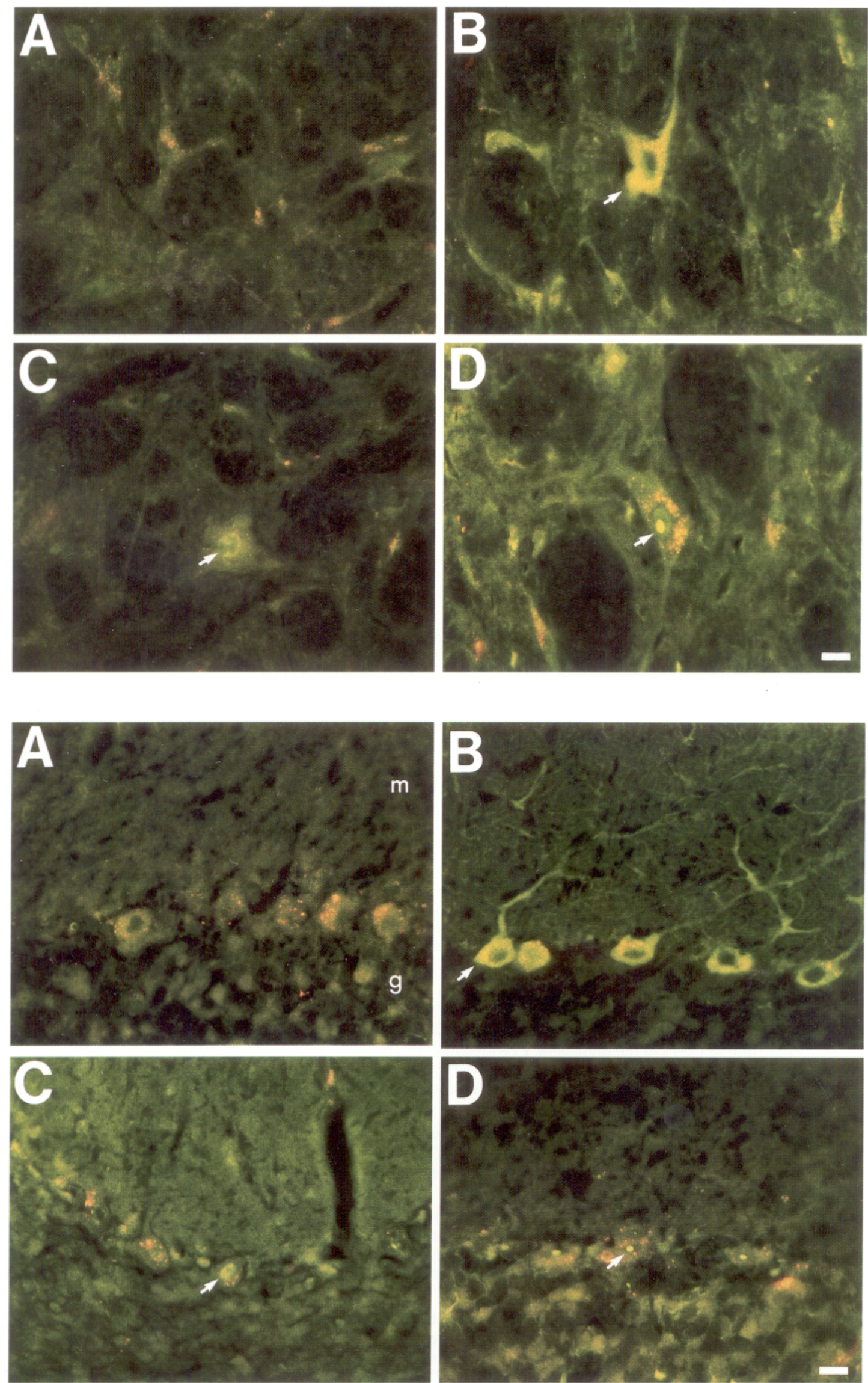

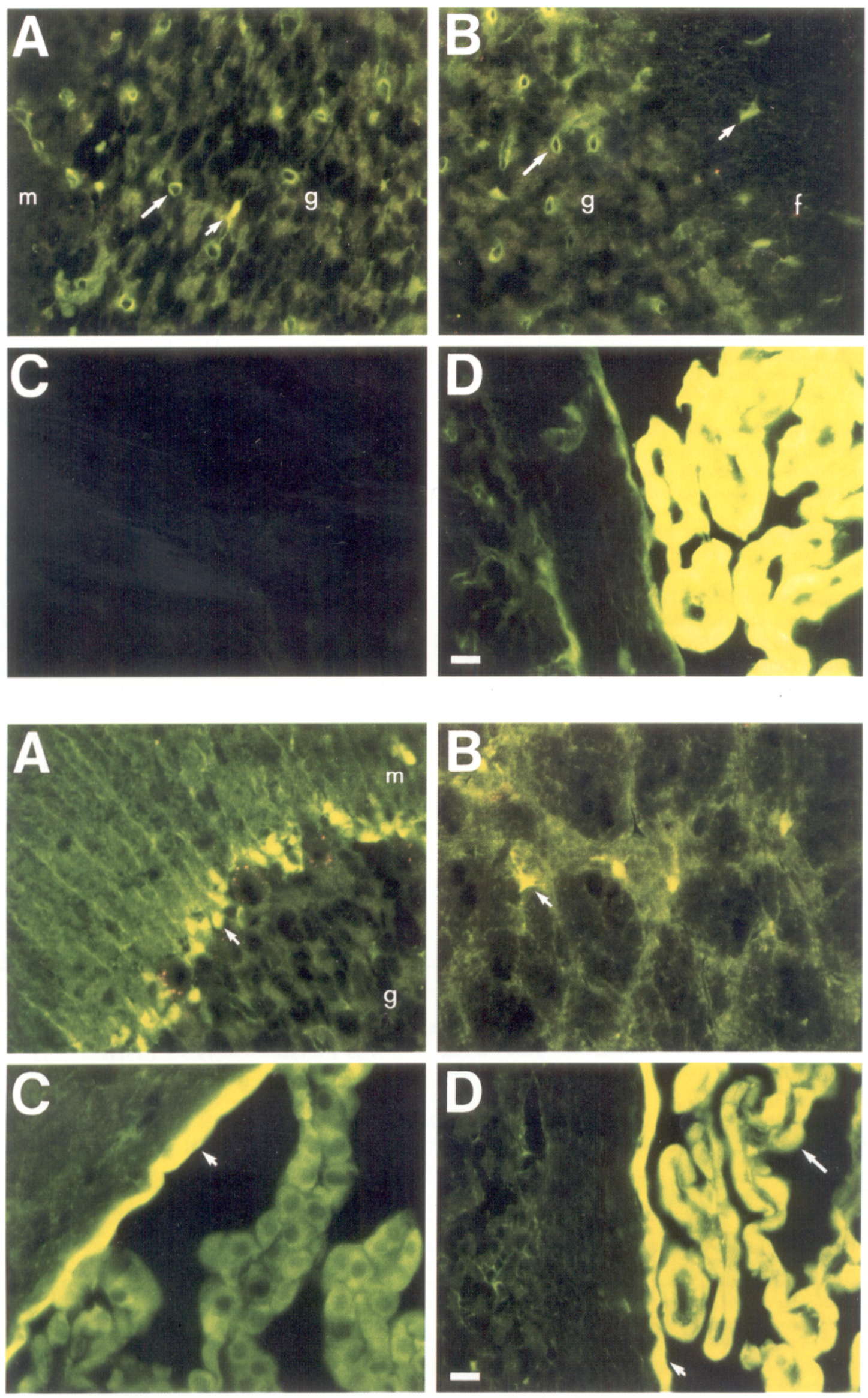
Table 1. Cytosolic GST activity and total cytosolic GST subunit protein in different brain regions of male Wistar rats

\begin{tabular}{lll} 
& $\begin{array}{l}\text { GST activity } \\
\text { (nmol/min/mg } \\
\text { protein) }\end{array}$ & $\begin{array}{l}\text { Total GST protein } \\
\text { (pmol/mg protein) }\end{array}$ \\
\hline $\begin{array}{l}\text { Cerebellum } \\
\text { Flocculus }\end{array}$ & $163 \pm 4.88 \ddagger \S \#$ & $53.3 \pm 3.96 \ddagger \S \#$ \\
Lateral & $177 \pm 5.44 \#$ & $56.6 \pm 1.71 \S \#$ \\
$\quad$ Vermis & $196 \pm 3.52^{*} \#$ & $63.7 \pm 1.94^{*} \S \#$ \\
Brainstem & $198 \pm 10.3^{*} \#$ & $73.0 \pm 1.74 \pi$ \\
Thalamus/hypothalamus & $300 \pm 9.66 \pi$ & $86.2 \pm 2.97 \pi$ \\
Cortex & $186 \pm 8.75 \#$ & $59.1 \pm 2.32 \S \#$
\end{tabular}

GST activity was measured by assaying the conjugation of 1-chloro-2,4-dinitrobenzene with GSH. Values are the means \pm SEM $(n=3)$ expressed as nmol of 1-chloro-2,4-dinitrobenzene conjugated $/ \mathrm{min} / \mathrm{mg}$ of cytosolic protein. The concentrations of individual subunits were determined by HPLC. These values were summed to determine the concentration of total GST subunit protein. Values are the means \pm SEM $(n=3)$ expressed as pmol of GSI subunit protein $/ \mathrm{mg}$ of cytosolic protein.

* Significantly different from the corresponding value for flocculus $(p<0.05)$. $\ddagger$ Significantly different from the corresponding value for vermis $(p<0.05)$. $\S$ Significantly different from the corresponding value for brainstem $(p<0.05)$. \# Significantly different from the corresponding value for thalamus/hypothalamus $(p<0.05)$.

I Significantly different from the corresponding values for all other brain regions $(p<0.05)$.

munopositive for microsomal GST (data not shown). The distribution of $\mu$ - and $\pi$-class-labeled glial cells was similar to that described by others (Senjo et al., 1986; Abramovitz et al., 1988; Cammer et al., 1989; Tansey and Cammer, 1991a,b). $\mu$-Class GST-immunoreactive Bergmann radial glia were found in all regions of the cerebellar cortex (Fig. 4A). $\mu$-Class GST 3-3 $\left(\mathrm{Y}_{\mathrm{b} 1} \mathrm{Y}_{\mathrm{b} 1}\right)$ and 4-4 $\left(\mathrm{Y}_{\mathrm{b} 2} \mathrm{Y}_{\mathrm{b} 2}\right)$ antibodies were reactive with astrocytes (Fig. $4 B$ ), pia mater, cells of the ependyma and subventricular zones (Fig. $4 C, D$ ), and choroid plexus (Fig. $4 D$ ). The patterns of immunoreactivity for $\mu$-class GST 3-3 $\left(Y_{b 1} Y_{b 1}\right)$ and 4-4 $\left(Y_{b 2} Y_{b 2}\right)$ were very similar, with the exception of the choroid plexus, which was consistently more immunopositive for GST 4-4 $\left(\mathrm{Y}_{\mathrm{b} 2} \mathrm{Y}_{\mathrm{b} 2}\right)$ than GST 3-3( $\left.\mathrm{Y}_{\mathrm{b} 1 \mathrm{~b} 1}\right)$ (Fig. 4C,D). $\pi$-Class GST 7-7 $\left(\mathrm{Y}_{\mathrm{p}} \mathrm{Y}_{\mathrm{p}}\right)$ was the only GST localized to oligodendrocytes (Fig. $5 B-D$ ). Furthermore, the choroid plexus was also immunopositive for $\pi$-class GST (Fig. 5D).

\section{Regional distribution of GST activity and GST subunits}

GSTs were isolated from different brain regions by affinity chromatography and the concentrations of individual subunits were determined by reverse-phase HPLC (Fig. 6). The regions examined included brainstem, cerebral cortex, thalamus/hypothalamus, and three regions of the cerebellar cortex: the flocculus, lateral hemispheres, and vermis. Brain regions differed with respect to total cytosolic GST activity and profiles of GST subunits (Tables 1-3). The thalamus/hypothalamus had the highest GST activity and the greatest concentration of GST subunit protein (Table 1). The brainstem had a significantly higher concentration of total GST subunit protein than the three regions of the cerebellar cortex; the same, however, was not true for GST activity (Table 1). This was due to the lower protein concentration of $\mu$-class GST subunits in brainstem compared to the cerebellar cortex (Tables 2,3 ), and the greater concentration of $\pi$-class GST subunit $7\left(\mathrm{Y}_{\mathrm{p}}\right)$ in brainstem compared to cerebellum (Tables 2,3). The lower specific activity of GSI 7-7 $\left(\mathrm{Y}_{\mathrm{p}} \mathrm{Y}_{\mathrm{p}}\right)$ compared to $\mu$-class GST proteins (Ketterer et al., 1988; Mannervik and Danielson, 1988; Vos and Van Bladeren, 1990) accounts for this discrepancy between total GST protein concentration and enzyme activity. In cerebellar cortex, the concentration of $\alpha$-class GSTs [subunit $2\left(\mathrm{Y}_{\mathrm{c} 1}\right)$ and subunit $8\left(\mathrm{Y}_{\mathrm{k}}\right)$ ] was threefold less than that in other brain regions (Tables 2,3 ). Such regional variation in GST expression may be reflective of regional differences in cell populations. Cytosolic $\alpha$-class GST subunits $1\left(\mathrm{Y}_{\mathrm{a} 1}\right)$ and $1^{\prime}\left(\mathrm{Y}_{\mathrm{a} 2}\right)$ were nol delected in any of the brain regions examined (Tables 2,3 ).

In cerebellar cortex, GST enzyme activity and the concentration of total GST subunit protein were significantly greater in

Table 2. Concentrations of cytosolic GST subunit protein in brain regions of the male Wistar rat

\begin{tabular}{llllll}
$\begin{array}{l}\text { GST } \\
\text { subunit }\end{array}$ & Flocculus & Lateral & Vermis & Brainstem & $\begin{array}{l}\text { Thalamus/ } \\
\text { hypothalamus }\end{array}$ \\
\hline $1\left(\mathrm{Y}_{\mathrm{a} 1}, \alpha\right)$ & - & - & - & - & - \\
Cortex
\end{tabular}

The protein concentrations of GST subunits present in each brain region were calculated from the reverse-phase HPLC profiles of affinity-purified GST pools. Values represent the means \pm SEM $(n=3)$ of pmol of GST subunit protein $/ \mathrm{mg}$ of cytosolic protein. Undetectable GST indicated by - .

* Significantly different from the corresponding value for flocculus $(y<0.05)$.

$\dagger$ Significantly different from the corresponding value for lateral $(p<0.05)$.

$\ddagger$ Significantly different from the corresponding value for vermis $(p<0.05)$.

$\S$ Significantly different from the corresponding value for brainstem $(p<0.05)$.

\# Significantly different from the corresponding value for thalamus/hypothalamus $(p<0.05)$.

I Significantly different from the corresponding value for cortex $(p<0.05)$.

@ Significantly different from the corresponding values for all other brain regions $(p<0.05)$. 
Table 3. Relative levels of cytosolic GST subunit protein in male Wistar rat brain

\begin{tabular}{llllll}
$\begin{array}{l}\text { GST } \\
\text { subunit }\end{array}$ & Flocculus & Lateral & Vermis & Brainstem & $\begin{array}{l}\text { Thalamus/ } \\
\text { hypothalamus }\end{array}$ \\
\hline $1\left(Y_{\mathrm{a} 1}, \alpha\right)$ & - & - & - & - & - \\
Cortex
\end{tabular}

The percentage of GST subunit protein present in each brain region was derived from the reverse-phase HPLC profiles of affinity-purified GST pools. Values represent the means \pm SEM $(n=3)$ of the percentage of subunit protein present with respect to the total GST subunit protein in a given brain region. Undetectable GST indicated by -.

* Significantly different from the corresponding value for flocculus $(p<0.05)$.

† Significantly different from the corresponding value for lateral $(p<0.05)$.

$\ddagger$ Significantly different from the corresponding value for vermis $(p<0.05)$.

$\$$ Significantly different from the corresponding value for brainstem $(p<0.05)$.

\# Significantly different from the corresponding value for thalamus/hypothalamus $(p<0.05)$.

II Significantly different from the corresponding value for cortex $(p<0.05)$.

(a) Significantly different from the corresponding value for all other brain regions $(p<0.05)$.

the vermis than in the lateral lobes and flocculus (Table 1). Similarly, the concentration of total $\mu$-class GST subunits [summation of concentrations of subunits $3\left(\mathrm{Y}_{\mathrm{b} 1}\right), 4\left(\mathrm{Y}_{\mathrm{b} 2}\right), 6\left(\mathrm{Y}_{\mathrm{b} 3}\right)$, and $\left.11\left(Y_{o}\right)\right]$ was greatest in the vermis (Table 2); the percentages of total $\mu$-class GST subunit protein in regions of the cerebellar cortex, however, were not significantly different (Table 3). Analysis of the protein concentrations of the individual $\mu$-class subunits demonstrated that the most significant difference in cerebellar regions occurred with respect to subunit $4\left(Y_{\mathrm{b} 2}\right)$ (Tables $2,3)$. There was a regional gradient in the pattern of $\mu$-class GST subunit $4\left(\mathrm{Y}_{\mathrm{b}_{2}}\right)$ expression. The flocculus had the highest concentration (Table 2) and greatest relative levels (Table 3 ) of subunit $4\left(\mathrm{Y}_{\mathrm{b} 2}\right)$, and the vermis the lowest. The concentrations of the $\mu$-class GST subunits $3\left(\mathrm{Y}_{\mathrm{b} 1}\right)$ and $11\left(\mathrm{Y}_{\mathrm{o}}\right)$ were significantly greater in the vermis than in either the flocculus or lateral lobes of the cerebellar cortex (Table 2). When expressed as percentage of total GST subunit protein, however, there was little regional variation in the levels of subunits $3\left(\mathrm{Y}_{\mathrm{b} 1}\right)$ and $11\left(\mathrm{Y}_{\mathrm{o}}\right)$ (Table 3).

\section{Discussion}

Our major findings are that (1) neurons throughout the brain contain GST; (2) microsomal GST is localized to neuronal soma; (3) $\alpha$-class GSTs are localized to the nucleus and nucleolus of neurons, and are also found in neuroglia and endothelial cells and/or astrocyte end-foot processes associated with blood vessels; (4) there are regional differences in the pattern of $\alpha-, \mu$-, and $\pi$-class GST subunit expression; and (5) in the cerebellum, the flocculus has a higher concentration of $\mu$-class GST subunit $4\left(\mathrm{Y}_{\mathrm{b} 2}\right)$ than the vermis.

Preliminary experiments resulted in the development of an immunohistochemical procedure that allowed us to identify, unequivocally, GST-positive neurons and glia in rat brain. Recently, an HPLC technique developed by Ostlund Farrants ct al. (1987) has greatly improved the ability to identify and quantify GST proteins (Ketterer et al., 1988; Kispert et al., 1989; Meyer et al., 1989, 1991; Hayes et al., 1990a; Hiratsuka et al.,
1990; Johnson et al., 1990, 1992a). We have increased the resolution and sensitivity of this HPLC technique and reduced the limit of detection to approximately $50 \mathrm{ng}$ of subunit protein. This improved HPLC technique has allowed us to characterize the GSTs in discrete brain regions.

Neither the $\alpha$-class nor microsomal GSTs have been studied extensively by immunohistochemistry in rat brain. Recently, Tansey and Cammer (1991b) suggested that $\alpha$-class GST 2-2 $\left(Y_{c} Y_{c}\right)$ is present in astrocytes, but they did not use other available $\alpha$-class antisera. Our data are consistent with the previous reports that $\mu$-class GSTs are present in astrocytes, Bergmann radial glia, and cells of the ependyma and the subventricular zones (Abramovitz et al., 1988; Cammer et al., 1989), and that $\pi$-class GST is localized to oligodendrocytes (Cammer et al., 1989; Tansey and Cammer, 199 la). We have also demonstrated that polyclonal antibody against microsomal GST was reactive with the cytoplasm of the perikaryon and proximal dendritic trunks of neurons in the brainstem, hippocampal neurons, and Purkinje cells of the cerebellar cortex. Nuclei of this same set of neurons were immunoreactive for $\alpha$-class GST 1-1 $\left(Y_{\mathrm{a}} \mathrm{Y}_{\mathrm{a}}\right)$, whereas the nucleolus, but not the nucleus or soma of these neurons, was immunoreactive with a related $\alpha$-class GST 2-2 $\left(\mathrm{Y}_{\mathrm{c}} \mathrm{Y}_{\mathrm{c}}\right)$ antibody. The nuclear localization of GSTs has been shown in numerous tissues, including rat pancreas ( $\pi$-class) (Daly et al., 1991), human liver ( $\alpha$-class) (Harrison et al., 1990b; Campbell et al., 1991), pia mater and choroid plexus of human brain ( $\pi$-class) (Carder et al., 1990), human ovary ( $\alpha$-class) (Rahilly et al., 1991), human breast tissue ( $\alpha$-, $\mu$-, and $\pi$-class) (Forrester et al., 1990; Cairns et al., 1992), and rat liver ( $\mu$-class) (Bennett et al., 1986). In contrast, specific immunohistochemical staining of the nucleolus with GST antibody has not been documented previously.

The function of nuclear and nucleolar GST(s) remains to be determined. Bennett et al. (1986) isolated a non-histone-binding protein (BA), which they determined was a mixture of $\mu$-class GSTs 3-3 $\left(Y_{b 1} Y_{b 1}\right)$ and 4-4 $\left(Y_{b 2} Y_{b 2}\right)$. These GST isoenzymes 

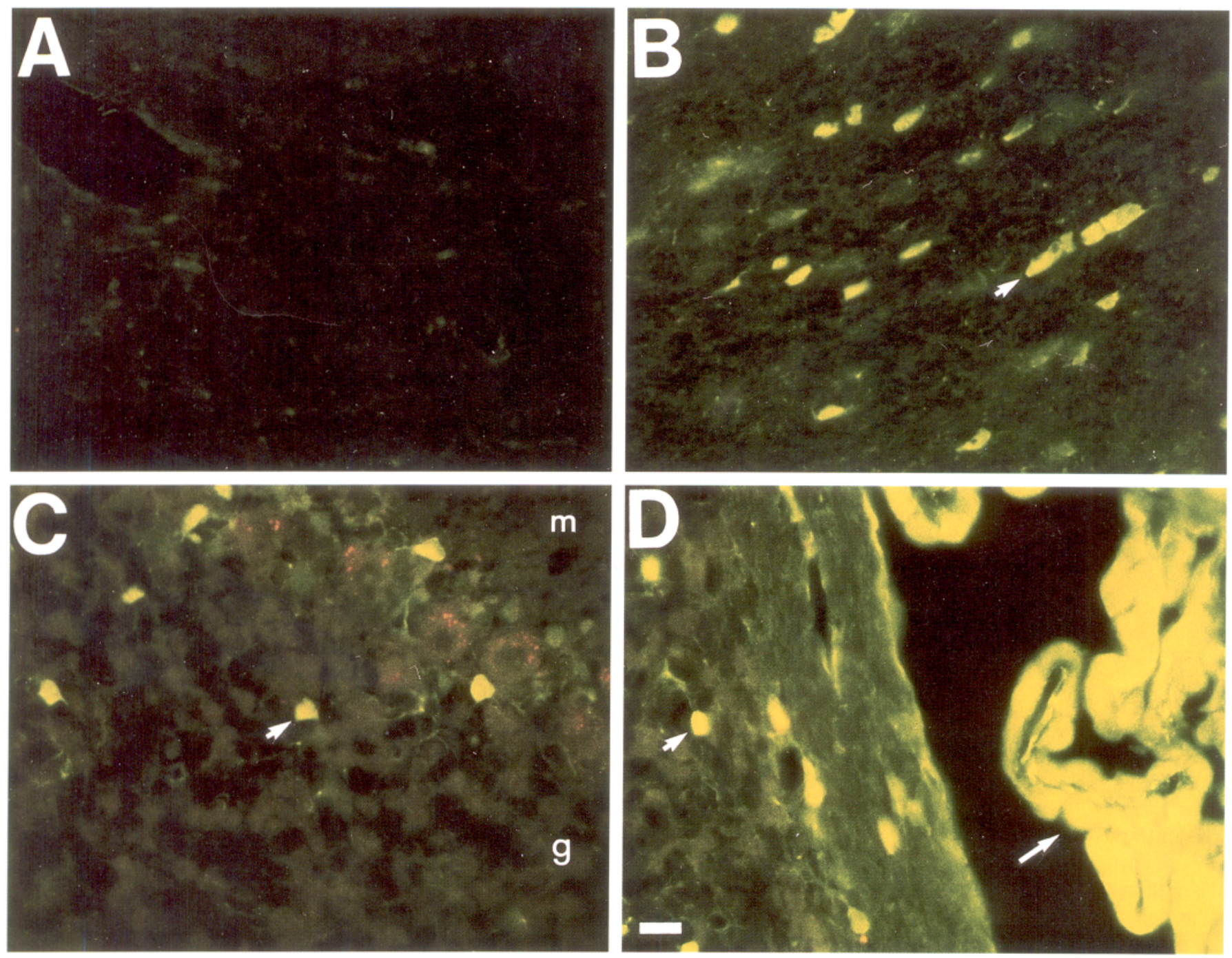

Figure 5. Immunohistochemical localization of $\pi$-class GST 7-7 $\left(\mathrm{Y}_{\mathrm{p}} \mathrm{Y}_{\mathrm{p}}\right)$ in the cerebellar cortex and choroid plexus. Cryosections $(10 \mu \mathrm{m})$ through fiber tracts of the cerebellar cortex $(A, B)$, molecular $(m)$ and granular $(g)$ layers of the cerebellar cortex $(C)$, and fourth ventricle $(D)$ were incubated with rabbit anti-rat $\pi$-class GST 7-7 $\left(\mathrm{Y}_{\mathrm{p}} \mathrm{Y}_{\mathrm{p}}\right)$ antiserum $(B, C, D)$ and preimmune rabbit serum $(A)$ as described in Figure 1 . Short arrows indicate immunopositive oligodendrocytes $(B, C, D)$; long arrow indicates positive choroid plexus $(D)$. Scale bar, $20 \mu \mathrm{m}$.

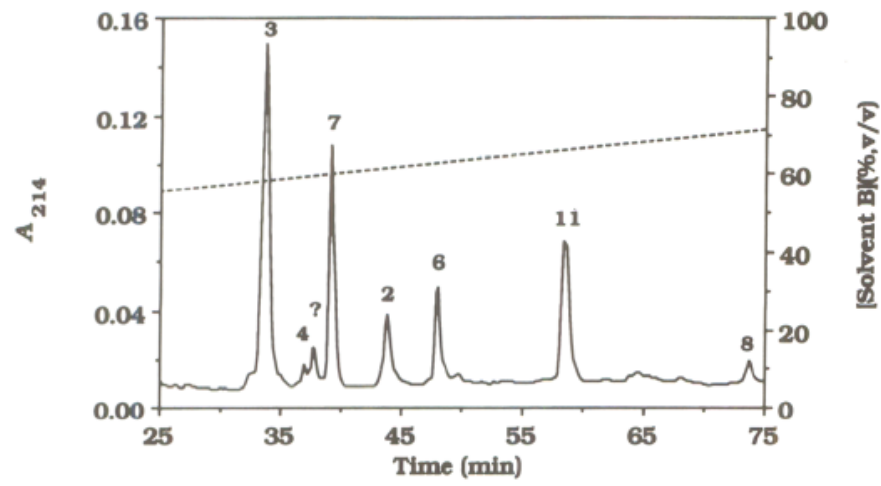

Figure 6. Reverse-phase HPLC of cytosolic GSTs isolated from cerebellar flocculi of male Wistar rat brain. Cytosolic GSTs were isolated by affinity chromatography from $4.0 \mathrm{mg}$ of cytosolic protein and subjected to analysis by reverse-phase HPLC. A gradient from $52 \%$ solvent B ( $70 \%$ acetonitrile, $0.1 \%$ TFA) to $74 \%$ solvent B over 70 min (broken line) separated the GST subunits. The absorbance at $214 \mathrm{~nm}$ was monitored (solid line). GST subunits were numbered as previously described by Jakoby et al. (1984), Mannervik and Danielson (1988), Ketterer et al. (1988), and Hayes et al. (1990b). were immunohistochemically colocalized with small nuclear ribonucleoproteins (snRNPs) to discrete nuclear regions in normal rat liver cells (Bennett et al., 1986). One hour after microinjection of purified and radiolabeled nuclear GSTs into cytoplasm of Walker 256 cells, over $85 \%$ of the labeled protein was associated with the nucleus (Bennett and Yeoman, 1987). These data suggest that GSTs may be involved in RNA processing and/or regulation of transcription (Bennett et al., 1986). In addition, since GSTs are present in the nucleolus as well as the nucleus, they could be involved in the production or regulation, or both, of ribosomes and snRNPs. GSTs have also been shown to modulate DNA adduct formation and may be involved in DNA repair after peroxide injury and in protection of DNA from oxidative damage (Ketterer et al., 1987; Liu et al., 1991). Finally, GSTs have been shown to take part in intracellular binding and transport of endogenous compounds including bilirubin, steroids, thyroid hormones, and neurotransmitters, as well as the removal of toxins and harmful metabolic byproducts (Abramovitz et al., 1988; Listowsky et al., 1988). 
Thus, GSTs may control the uptake and release of such compounds in brain via a GSH-dependent binding to GST.

Philbert et al. (1991) have recently described the regional and cellular distribution of GSH in the nervous system. In general, neuronal soma throughout the CNS were negative for GSH histochemical staining. In the cerebellum, however, both granule cells and Purkinje cells were stained positively for GSH (Philbert et al., 1991). These investigators also showed that GSH was present throughout the CNS neuropil and noted that the choroid plexus was intensely stained for GSH. Although all the GST antisera used in our experiments were immunoreactive with choroid plexus to varying degrees, the reactivity of $\alpha$-class GST 8-8 $\left(Y_{k} Y_{k}\right)$ antibody was particularly intense. Furthermore, GST 8-8 $\left(Y_{k} Y_{k}\right)$ antiserum showed specific immunoreactivity to endothelial cells and/or astrocyte end-foot processes associated with blood vessels throughout the brain. This colocalization of GST and GSH supports the proposal that GSTs may control the uptake and release of various compounds and the removal of toxins and harmful metabolic byproducts via a GSH-dependent binding to GST (Abramovitz et al., 1988; Listowsky et al., 1988). This may explain the decreased induction of glycerolphosphate dehydrogenase by hydrocortisone administration in GSH-depleted rats (Tansey and Cammer, 1991b). Based on these data, it is proposed that one function of GSTs is transport of hydrocortisone between or within neurons and glia. Furthermore, GST 8-8 $\left(Y_{k} Y_{k}\right)$ has remarkably high activity toward 4-hydroxyalkenals, which are prominent endogenous clcctrophiles produced as byproducts of metal-catalyzed decomposition of polyunsaturated fatty acyl hydroperoxides (Ketterer et al., 1988). Thus, the high level of $\alpha$-class GST 8-8 $\left(\mathrm{Y}_{\mathrm{k}} \mathrm{Y}_{\mathrm{k}}\right)$ expression associated with choroid plexus and blood vessels may also be a critical factor in neuroprotection.

Regional expression of $\mu$-class GST subunit $4\left(Y_{b 2}\right)$ in the cerebellum coincides with the regions most resistant to degeneration after exposure to toxic or metabolic insults. The vermis is more susceptible to these insults than the lateral lobes and flocculus. These regional differences in susceptibility are well illustrated by the observations that both an extensive loss of Purkinje cells and glial proliferation occur in the anterior portion of the cerebellar vermis in the Wernicke-Korsakoff syndrome (Victor, 1976) and in nutritional cerebellar degeneration (Adams, 1976), whereas in the posterior region and flocculi these neurons are spared. Cerebellar dysgenesis in humans has also been associated with neonatal cystic kidney disease (Kornguth et al., 1977; Marin-Padilla, 1989), autism (Courchesne et al., 1988), trisomy 21 (Warkany et al., 1966), fragile $X$ syndrome (Reiss et al., 1988), paraneoplastic cerebellar degeneration (Chen et al., 1990), and Joubert syndrome (Lambert et al., 1989). In nonhuman mammals, alcohol exposure in utero (Kornguth et al., 1979; Bonthius and West, 1991), hyperbilirubinemia (Schutta and Johnson, 1967; Sawasaki et al., 1976; Takagishi and Yamamura, 1989), methadone withdrawal (Zagon and McLaughlin, 1978), exposure to mutated diphtheria toxin (Riedel et al., 1990), hypothyroidism (Kornguth et al., 1967; Nicholson and Altman, 1972; Kornguth et al., 1979; Legrand, 1979; Silva and Rudas, 1990), and malnutrition (Neville and Chase, 1971; Patel et al., 1973; Yu et al., 1974; Sima and Persson, 1975; Gopinath et al., 1976; McConnell and Berry, 1978) all result in maldevelopment of the ccrebellar cortex.

Cytosolic GST activity, total concentration of GST subunit protein, and the concentration of $\mu$-class GST subunits were not demonstrably different between the regions of the cerebellar cortex. This might suggest that all regions of the cerebellum would be equally susceptible to toxic agents. However, there is a region-specific loss of Purkinje cells due to toxic or metabolic insult, and this pattern of Purkinje cell loss was inversely correlated with the distribution of $\mu$-class GST subunit $4\left(\mathrm{Y}_{\mathrm{b} 2}\right)$. The cytoplasmic localization of microsomal GST in neurons, the nuclear localization of $\alpha$-class GSTs in neurons, and the relationship between the concentration of $\mu$-class GST subunit 4 $\left(Y_{b 2}\right)$ and resistance of neurons to toxic events in the cerebellar cortex suggest that GSTs may confer protection against exogenous and/or endogenous neurotoxic metabolites. Preliminary work in our laboratory using the Gunn rat as a model for hyperbilirubinemia supports this suggestion (Johnson et al., in press).

\section{References}

Abramovitz M, Listowsky I (1987) Selective expression of a unique glutathione $S$-transferase $Y_{b 3}$ gene in rat brain. J Biol Chem 262: 7770-7773.

Abramovitz M, Homma H, Ishigaki S, Tansey F, Cammer W, Listowsky 1 (1988) Characterization and localization of glutathione- $S$-transferases in rat brain and binding of hormones, neurotransmitters, and drugs. J Neurochem 50:50-57.

Adams RD (1976) Nutritional cerebellar degeneration. In: Handbook of clinical neurology (Vincken P, Bruyn G, eds), pp 271-284. Amsterdam: Elsevier/North Holland.

Bennett CF, Yeoman LC (1987) Microinjected glutathione $S$-transferase $Y b$ subunits translocate to the cell nucleus. Biochem $J$ 247: 109-112.

Bennett CF, Spector DL, Yeoman LC (1986) Nonhistone protein BA is a glutathione $S$-transferase localized to interchromatinic regions of the cell nucleus. J Cell Biol 102:600-609.

Benson AM, Hunkeler MJ, York JL (1989) Mouse hepatic glutathione transferase isoenzymes and their differential induction by anticarcinogens: specificities of butylated hydroxyanisole and bisethylxanthogen as inducers of glutathione transferases in male and female CD-1 mice. Biochem J 261:1023-1029.

Bonthius DJ, West JR (1991) Permanent neuronal deficits in rats exposed to alcohol during the brain growth spurt. Teratology $44: 147-$ 163.

Bradford MM (1976) A rapid and sensitive method for the quantifcation of microgram quantities of protein utilizing the principle of protein-dye binding. Anal Biochem 72:248-254

Cairns J, Wright C, Cattan AR, Hall AG, Cantwell BJ, Harris AL, Horne CHW (1992) Immunohistochemical demonstration of glutathione $S$-transferases in primary human breast carcinomas. J Pathol 166: 19-25.

Cammer W, Tansey F, Abramovitz M, Ishigaki S, Listowsky I (1989) Differential localization of glutathione- $S$-transferase $Y_{p}$ and $Y_{b}$ subunits in oligodendrocytes and astrocytes of rat brain. J Neurochem 52:876-883.

Campbell JAH, Corrigall AV, Guy A, Kirsch RE (1991) Immunohistologic localization of alpha, mu, and pi class glutathione $S$-transferases in human tissues. Cancer 67:1608-1613.

Carder PJ, Hume R, Fryer AA, Strange RC, Lauder J, Bell JE (1990) Glutathione $S$-transferase in human brain. Neuropathol Appl Neurobiol 16:293-303.

Chen YT, Rettig WJ, Yenamandra AK, Kozak CA, Chaganti RS, Posner JB, Old LJ (1990) Cerebellar degeneration-related antigen: a highly conserved ncuroectodermal marker mapped to chromosome $\mathrm{X}$ in human(s) and mouse. Proc Natl Acad Sci USA 87:3077-3081.

Courchesne E, Yeung-Courchesne R, Press GA, Hesselink JR, Jernigan TL (1988) Hypoplasia of cerebellar vermal lobules VI and VII in autism. New Engl J Med 318:1349-1354.

Cowan KH, Batist G, Tulpule A, Sinha BK, Myers CE (1986) Similar biochemical changes associated with multidrug resistance in human breast cancer cells and carcinogen-induced resistance to xenobiotics in rats. Proc Natl Acad Sci USA 83:9328-9332.

Daly JM, Tee LBG, Oates PS, Morgan RGH, Yeoh GCT (1991) Glutathione $S$-transferase (mu-class) as an early marker of azaserineinduced foci in the rat pancreas. Carcinogenesis 12:1237-1240.

Ding GJF, Ding VDH, Rodkey JA, Bennett CD, Lu AYH, Pickett CB 
(1986) Rat liver glutathione $S$-transferases: DNA sequence analysis of a $Y_{b 2}$ cDNA clone and regulation of the $Y_{b 1}$ and $Y_{b 2}$ mRNAs by phenobarbital. J Biol Chem 261:7952-7957.

Di Simplicio P, Jensson H, Mannervik B (1989) Effects of inducers of drug metabolism on basic hepatic forms of mouse glutathione transferase. Biochem J 263:679-685.

Forrester LM, Hayes JD, Millis R, Barnes D, Harris AL, Schlager JJ, Powis G, Wolf CR (1990) Expression of glutathione $S$-transferases and cytochrome $\mathrm{P} 450$ in normal and tumor breast tissue. Carcinogenesis 11:2163-2170.

Gopinath G, Bijlani V, Deo M (1976) Undernutrition and the developing cerebellar cortex in the rat. J Neuropathol Exp Neurol 35:125135.

Habig WH, Jakoby WB (1981) Assays for differentiation of glutathione $S$-transferases. Methods Enzymol 77:398-405.

Harris JM, Meyer DJ, Coles B, Ketterer B (1991) A novel glutathione transferase (13-13) isolated from the matrix of rat liver mitochondria having structural similarity to class theta enzymes. Biochem J 278 : 137-141.

Harrison DJ, May L, Hayes JD, Neal GE (1990a) Glutathione $S$-transferase localization in aflatoxin $\mathrm{B}_{1}$-treated rat livers. Carcinogenesis 11:927-931.

Harrison DJ, May L, Hayes PC, Haque MM, Hayes JD (1990b) Glutathione $S$-transferases in alcoholic liver disease. Gut 31:909-912.

Hayes JD (1988) Selective elution of rodent glutathione $S$-transferases and glyoxalase I from the $S$-hexylglutathione-Sepharose affinity matrix. Biochem J 255:913-922.

Hayes JD, Mantle TJ (1986a) Use of immunoblot techniques to discriminate between the glutathione $S$-transferase $Y_{n}, Y_{k}, Y_{n} / Y_{b}$, and $Y_{c}$ subunits and to study their extra-hepatic distribution: evidence for three immunochemically distinct groups of transferase in the rat. Biochem J 233:779-788.

Hayes JD, Mantle TJ (1986b) Anomalous electrophoretic behaviour of the glutathione $S$-transferase $Y_{a}$ and $Y_{k}$ subunits isolated from man and rodents: a potential pitfall for nomenclature. Biochem J 237:731740.

Hayes JD, Kerr LA, Harrison DJ, Cronshaw AD, Ross AG, Neal GE (1990a) Preferential over-expression of the class alpha rat $Y_{a 2}$ glutathione $S$-transferase subunit in livers bearing aflatoxin-induced preneoplastic nodules: comparison of the primary structures of $Y_{\mathrm{a} 1}$ and $Y_{\mathrm{a} 2}$ with cloned class alpha glutathione $S$-transferase cDNA sequences. Biochem J 268:295-302.

Hayes JD, Pickett CB, Mantle TJ (1990b) Preface. In: Glutathione $S$-transferases and drug resistance (Hayes JD, Pickett CB, Mantle TJ, eds), pp ix-xv. London: Taylor and Francis.

Hayes JD, Judah DJ, McLellan LI, Kerr LA, Peacock SD, Neal GE (1991) Ethoxyquin-induced resistance to aflatoxin $B_{1}$ in the rat is associated with the expression of a novel alpha-class glutathione $S$-transferase subunit, $Y_{\mathrm{c} 2}$, which possesses high catalytic activity for aflatoxin $B_{1}-8,9$-epoxide. Biochem J 279:385-398.

Hiratsuka A, Sebata N, Kawashima K, Okuda H, Ogura K, Watabe T, Satoh K, Hatayama I, Tsuchida S, Ishikawa T, Sato K (1990) A new class of rat glutathione $S$-transferase $Y_{\mathrm{rs}}-Y_{\mathrm{rs}}$ inactivating reactive sulfate esters as metabolites of carcinogenic arylmethanols. J Biol Chem 265:11973-11981.

Jakoby WB, Ketterer B, Mannervik B (1984) Glutathione transferases: nomenclature. Biochem Pharmacol 33:2539-2540.

Johnson JA, Neal TL, Collins JH, Siegel FL (1990) Characterization of methylation of rat liver cytosolic glutathione $S$-transferases by using reverse-phase h.p.l.c. and chromatofocusing. Biochem J 270: 483-489.

Johnson JA, El Barbary A, Kornguth SE, Brugge JF, Siegel FL (1991) Brain glutathione $S$-transferase (GST) activity and isoenzyme profiles in the Gunn rat. Soc Neurosci Abstr 17:1460.

Johnson JA, Finn KA, Siegel FL (1992a) Tissue distribution of enzymic methylation of glutathione $S$-transferase and its effects on catalytic activity: methylation of glutathione $S$-transferase 11-11 inhibits conjugating activity towards 1 -chloro-2,4-dinitrobenzene. Biochem J 282:279-289.

Johnson JA, El Barbary A, Kornguth SE, Brugge JF, Siegel FL (1992b) Glutathione $S$-transferase (GST) isoenzyme profiles and activity in brain regions of the Gunn rat. Toxicologist 12:323.

Johnson JA, Hayward JJ, Kornguth SE, Siegel FL (in press) Effects of hyperbilirubinaemia on glutathione $S$-transferase isoenzymes in cerebellar cortex of the Gunn rat. Biochem J, in press.
Ketterer B, Tan KH, Meyer DJ, Coles B (1987) Glutathione $S$-transferases: possible role in the detoxification of DNA and lipid hydroperoxides. In: Glutathione $S$-transferases and carcinogenesis (Mantle TJ, Pickett CB, Hayes JD, eds), pp 149-163. London: Taylor and Francis.

Ketterer B, Meyer DJ, Clark AG (1988) Solubleglutathione transferase isozymes. In: Glutathione conjugation: mechanism and biological significance (Sies H, Ketterer B, eds), pp 73-135. London: Academic.

Kispert A, Meyer DJ, Lalor E, Coles B, Ketterer B (1989) Purification and characterization of a labile rat glutathione transferase of the mu class. Biochem J 260:789-793.

Kornguth SE, Anderson J, Scott G (1967) Observations on the ultrastructure of the developing cerebellum of Macaca mulatta. J Comp Neurol 130:1-24.

Kornguth SE, Knobeloch L, Viseskul C, Gilbert EF, Opitz JM (1977) Defect of cerebellar Purkinje cell histogenesis associated with type I and type II renal cystic disease. Acta Neuropathol (Berl) 40:1-9.

Kornguth SE, Rutledge JJ, Sunderland E, Siegel F, Carlson I, Smollens J, Juhl U, Young B (1979) lmpeded cerebellar development and reduced serum thyroxine levels associated with fetal alcohol intoxication. Brain Res 177:347-360.

Lambert SR, Kriss A, Gresty M, Benton S, Taylor D (1989) Joubert syndrome. Arch Ophthalmol (Copenh) 107:709-713.

Lee E, Okuno S, Kariya K (1986) Propylthiouracil inducible glutathione transferases. Biochem Pharmacol 35:1835-1839.

Legrand C, Clos J (1991) Biochemical, immunocytochemical, and morphological evidence for an interaction between thyroid hormone and nerve growth factor in the developing cerebellum of normal and hypothyroid rats. Dev Neurosci 13:382-396.

Legrand J (1979) Morphogenetic action of thyroid hormones. Trends Neurosci 2:234-236.

Li NQ, Reddanna P, Thyagaraju K, Reddy CC, Tu CPD (1986) Expression of glutathione $S$-transferases in rat brains. J Biol Chem 261 : 7596-7599.

Listowsky I, Abramovitz M, Homma H, Niitu Y (1988) Intracellular binding and transport of hormones and xenobiotics by glutathione $S$-transferases. Drug Metab Rev 19:305-318.

Liu YH, Taylor J, Linko P, Lucier GW, Thompson CI. (1991) Glutathione $S$-transferase $\mu$ in human lymphocyte and liver: role in modulating formation of carcinogen-derived DNA adducts. Carcinogenesis 12:2269-2275.

Mannervik B, Danielson UH (1988) Glutathione transferases-structure and catalytic activity. CRC Crit Rev Biochem 23:283-337.

Mannervik B, Guthenberg C (1981) Glutathione transferase (human placenta). Methods Enzymol 77:231-235.

Marin-Padilla M (1989) Abnormal Purkinje cell morphogenesis in human renal agenesis: a Golgi study. J Neuropathol Exp Neurol 48: 448-461.

McConnell P, Berry M (1978) The effects of undernutrition on Purkinje cells dendritic growth in the rat. J Comp Neurol 177:159-172.

McLellan LI, Hayes JD (1989) Differential induction of class alpha glutathione $S$-transferases in mouse liver by the anticarcinogenic antioxidant butylated hydroxyanisole: purification and characterization of glutathione $S$-transferase $Y_{\mathrm{a} 1} Y_{\mathrm{a} 1}$. Biochem J 263:393-402.

McLellan LI, Kerr LA, Cronshaw $\Lambda$ D, Hayes JD (1991) Regulation of mouse glutathione $S$-transferases by chemoprotectors: molecular evidence for the existence of three distinct alpha-class glutathione $S$-transferase subunits $\mathrm{Y}_{\mathrm{a} 1}, \mathrm{Y}_{\mathrm{a} 2}$ and $\mathrm{Y}_{\mathrm{a} 3}$, in mouse liver. Biochem $\mathrm{J}$ 276:461-469.

Meyer DJ, Lalor E, Coles B, Kispert A, Ålin P, Mannervik B, Ketterer B (1989) Single-step purification and HPLC analysis of glutathione transferase 8-8 in rat tissues. Biochem J 260:785-788.

Meyer DJ, Coles B, Pemble SE, Gilmore KS, Fraser GM, Ketterer B (1991) Theta, a new class of glutathione transferases purified from rat and human. Biochem J 274:409-414.

Morgenstern R, De Pierre JW (1985) Microsomal glutathione transferase: a review. In: Reviews in biochemical toxicology (Hogdson JR, Bend JR, Philpot RM, eds), pp 67-104. New York: Elsevier/North Holland.

Morgenstern R, De Pierre JW, Jörnvall H (1985) Microsomal glutathione transferase: primary structure. J Biol Chem 260:13976-13983.

Moscow JA, Fairchild CR, Madden MJ, Ransom DT, Wieand HS, O'Brien EE, Poplack DG, Cossman J, Myers CE, Cowan KH (1989) Expression of anionic glutathione- $S$-transferase and P-glycoprotein genes in human tissues and tumors. Cancer Res 49:1422-1428. 
Murata T, Hatayama I, Satoh K, Tsuchida S, Sato K (1990) Activation of rat glutathione transferases in class $\mathrm{mu}$ by active oxygen species. Biochem Biophys Res Commun 171:845-851.

Neal TL, Wright LS, Siegel FL (1988) Identification of glutathione $S$-transferase as a substrate and glutathione as an inhibitor of in vitro calmodulin-stimulated protein methylation in rat liver cytosol. Biochem Biophys Res Commun 156:368-374.

Neville H, Chase H (1971) Undernutrition and cerebellar development. Exp Neurol 33:458-497.

Nicholson J, Altman J (1972) Effects of carly hypothyroidism and hyperthyroidism on the development of rat cerebellar cortex. Brain Res 44:13-23.

Ostlund Farrants AK, Meyer DJ, Coles B, Southan C, Aitken A, Johnson PJ, Ketterer B (1987) The separation of glutathione transferase subunits by using reverse-phase high-pressure liquid chromatography. Biochem J 245:423-428.

Patel A, Balazs R, Johnson A (1973) Effect of undernutrition on cel formation in the rat brain. $J$ Neurochem 20:1151-1165.

Philbert MA, Beiswanger CM, Waters DK, Reuhl KR, Lowndes HE (1991) Cellular and regional distribution of reduced glutathione in the nervous system of the rat: histochemical localization by mercury orange and $o$-phthaldialdehyde-induced histofluorescence. Toxicol Appl Pharmacol 107:215-227.

Pickett CB, Telakowski-Hopkins CA, Ding GJF, Argenbright L, Lu AYH (1984) Rat liver glutathione $S$-transferases: complete nucleotide sequence of a glutathione $S$-transferase mRNA and the regulation of the $Y_{a}, Y_{b}$, and $Y_{c}$ mRNAs by 3-methylcholanthrene and phenobarbital. J Biol Chem 259:5182-5188.

Pyerin W, Taniguchi H, Horn F, Oesch F, Amelizad Z, Friedberg T, Wolf CR (1987) Isoenzyme-specific phosphorylation of cytochrome P450 and other drug metabolizing enzymes. Biochem Biophys Res Commun 142:885-892.

Rahilly M, Carder PJ, Al Nafussi A, Harrison DJ (1991) Distribution of glutathione $S$-transferase isoenzymes in human ovary. J Reprod Fertil 93:303-311.

Reiss AL, Patel S, Kumar AJ, Freund L (1988) Preliminary communication: neuroanatomical variations of the posterior fossa in men with fragile X (Martin-Bell) syndromc. Am J Med Genet 31:407414.

Riedel C, Muraszko KM, Youle RJ (1990) Diphtheria toxin mutant selectively kills cerebellar Purkinje neurons. Proc Natl Acad Sci USA 87:5051-5055.

Rushmore TH, King RG, Paulson KE, Pickett CB (1990) Regulation of glutathione $S$-transferase $Y_{\mathrm{a}}$ subunit gene expression: identification of a unique xenobiotic-responsive element controlling inducible expression by planar aromatic compounds. Proc Natl Acad Sci USA $87: 3826-3830$.

Satoh K, Kitahara A, Soma Y, Inaba Y, Hatayama I, Sato K (1985) Purification, induction, and distribution of placental glutathione transferase: a new marker enzyme for preneoplastic cells in the rat chemical hepatocarcinogenesis. Proc Natl Acad Sci USA 82:39643968.

Sawasaki Y, Yamada N, Nakajima H (1976) Developmental features of cerebellar hypoplasia and brain bilirubin levels in a mutant (Gunn) rat with hereditary hyperbilirubinemia. J Neurochem 27:577-583.
Schutta HS, Johnson L (1967) Bilirubin encephalopathy in the Gunn rat: a fine structure study of the cerebellar cortex. J Neuropathol Exp Neurol 26:377-396.

Senjo M, Ishibashi T (1985) Immunocytochemical demonstration of specific localization of glutathione $S$-transferases in astrocytes and ependymal cells of rat brain. Biomed Res 6:433-436.

Senjo M, Ishibashi T, Terashima T, Inoue Y (1986) Successive appearance of glutathione $S$-transferase-positive cells in developing rat brain: choroid plexus, pia mater, ventricular zone and astrocytes. Neurosci Lett 66:131-134.

Silva JE, Rudas P (1990) Effects of congenital hypothyroidism on microtubule-associated protein-2-expression in the cerebellum of the rat. Endocrinology 126:1276-1282.

Sima A, Persson L (1975) The effect of pre- and post-natal undernutrition on the development of rat cerebellar cortex. Neurobiology 5:23-34.

Simons PC, Vander Jagt DL (1981) Purification of glutathione $S$-transferases by glutathione-affinity chromatography. Methods Enzymol 77 : 235-237.

Steinberg P, Schramm H, Schladt L, Robertson LW, Thomas H, Oesch $F$ (1989) The distribution, induction and isoenzyme profile of glutathione $S$-transferase and glutathione peroxidase in isolated rat liver parenchymal, Kupfer and endothelial cells. Biochem J 264:737-744.

Takagishi Y, Yamamura H (1989) Purkinje cell abnormalities and synaptogenesis in genetically jaundiced rats (Gunn rats). Brain Res 492:116-128.

Taniguchi H, Pyerin W (1989) Glutathione $S$-transferase in an in vitro substrate of $\mathrm{Ca}^{++}$-phospholipid-dependent protein kinase (protein kinase C). Biochem Biophys Res Commun 162:903-907.

Tansey FA, Cammer W (1991a) A pi form of glutathione $S$-transferase is a myelin- and oligodendrocyte-associated enzyme in mouse brain. J Neurochem 57:95-102.

Tansey FA, Cammer W (1991b) Depletion of glutathione interferes with induction of glycerolphosphate dehydrogenase in the brains of young rats. Brain Res 564:31-36.

Tsuchida S, Sato K (1990) Rat spleen glutathione transferases: a new acidic form belonging to the alpha class. Biochem $\mathrm{J}$ 266:461-465.

Tu CPD, Weiss MJ, Li NQ, Reddy CC (1983) Tissue-specific expression of the rat glutathione $S$-transferases. J Biol Chem 258:46594662.

Victor M (1976) Wernicke-Korsakoff syndrome. In: Handbook of clinical neurology (Vincken P, Bruyn G, eds), pp 243-270. Amsterdam: Elsevier/North Holland.

Vos RME, Van Bladeren PJ (1990) Glutathione $S$-transferases in relation to their role in the biotransformation of xenobiotics. Chem Biol Interact 75:241-265.

Warkany J, Passarge E, Smith L (1966) Congenital malformations in autosomal trisomy conditions. Am J Dis Child 112:502-517.

Yu M, Lee J, Bakay L (1974) The ultrastructure of the rat central nervous system in chronic undernutrition. Acta Neuropathol (Berl) 30:197-210.

Zagon I, McLaughlin P (1978) Perinatal methadone cxposure and brain development: a biochemical study. J Neurochem 31:49-54. 